\title{
The beginning phases of the early childhood caries (circular caries) - clinical evaluation of remineralization
}

\author{
Olga Kokoceva-Ivanovska
}

\author{
Department of Pediatric Dentistry, Faculty of Stomatology, \\ Ss. Cyril and Methodius University, Str. Majka Tereza 17, \\ 1000 Skopje, Republic of North Macedonia
}

Received: June 2020; Accepted: July 2020

\begin{abstract}
Early childhood caries (circular caries) can occur at an early age, with the eruption of deciduous teeth of the age of 1 to 1.5 years old. This is a multifactorial dental disease that has become a worldwide problem with high prevalence in recent decades. The purpose of the study was clinical evaluation of the remineralizing effect of the topical treatment, in patients with starting stages of circular caries.

This study was conducted at the Clinic for Pediatric and Preventive Dentistry, Skopje, and included 117 patients of both sexes, with the starting stages of circular caries. They were aged of 1.5 to 3.5 years old, with a fully formed primary tooth. It was selected 61 patients with initial lesion - white spot and 56 patients with superficial form. From both groups 30 patients were treated with topical fluoride preparation, for a period of six months, applied once a week. The remaining patients had regular check-ups and instructions, but they did not undergo fluoride treatment.

After the fluoride treatment, we followed the remineralizing effect, i.e. which initial lesions were reversed or where the intracrystal spaces were filled and the crystals were repaired after six months of topical application. In some patients who were able to satisfy other preventative factors, we were able to obtain a clinical picture of complete remineralization on initial lesion (restitution ad integrum) in vivo, approximately similar to a healthy tooth. How successful the remineralization will be depends on the predominant, protective, or pathogenic factors.
\end{abstract}

Keywords: circular caries, early childhood caries, remineralization, initial lesion, white spot

\section{Introduction}

Dental caries is a dynamic group of complex physical-chemical processes on the tooth surface that occur in vivo, with alternating periods of demineralization and remineralization and numerous interacting processes leading to imbalance and mineral loss (Biesbrock, 1988; Carčev, 2009; Catean Arends, 1980; Gajic, 1998; Kokoceva, 2011). Enamel demineralization is a process of mineral lost. During this process, calcium and phosphate ions from hydroxyl apatite crystal pass into the plaque and saliva. In fact, the carious lesion occurs in two separate stages. The early stage (initial lesion) is known as macula alba, or white spot, which is reversible (Hoyer and Gaengler, 1984). At this stage the caries has not completely penetrated the enamel border. At the moment when caries penetrates, it spreads along border and then cavitation occurs, i.e. caries, due to cracking of the enamel surface. Beneath the surface of the initial carious lesion or white spot, there is a section of lost minerals just below the intact surface of the enamel. That surface with fewer minerals is capable of a reversible remineralization process (Van Loveren and Amaechi, 2013). As

\footnotetext{
*olga.kokoceva@gmail.com
} 
acknowledge, it is possible for calcium and phosphate ions to diffuse into the initial lesion to restore the lost apatite in a process referred to as remineralization. Remineralization is described as a process of deposition of mineral ions, primarily calcium and phosphates, in the initial carious lesion (Cochrane and Saranathan, 2008), which during the demineralization process passed from the surface layers of the enamel to the plaque and saliva. With remineralization, hydroxyl apatite increase and if fluoride is present in the medium, fluorapatite will be formed. Thus, fluoride is the most common remineralization agent. Remineralization treatment for active initial unvaccinated carious lesion, allows process reversibility or at least stopping progression to cavitation (Lynch and Smith, 2012). How successful remineralization will be depends on the predominant, protective, or pathogenic factors (Vashisht and Indira, 2013).

The initial carious lesion occurs very early in deciduous teeth, immediately after their eruption in early childhood (1-2.5 years). It is a specific type of caries that only affects the deciduous teeth. In the latest professional terminology "Early childhood caries" (Muller, 1996) referred to circular caries, which is of interest for many epidemiological, clinical studies, laboratory tests, etc., all over the world in order to prevent its occurrence and reduce high prevalence (Kokoceva-Ivanovska, 2011; Louloudiadis et al., 2001).

In the initial lesion stage, with the removal of caries and the causative agent (dental plaque) on the one hand, and taking maximum preventive measures on the other hand (Roopa and Pathak, 2015), such as: proper nutrition of the young child, normal $\mathrm{pH}$ and saliva composition, adequate mechanical and chemical control of dental plaque, maintaining proper oral hygiene and applying topical fluoride preparations in various forms, conditions are created for the predominance of remineralization processes in relation to demineralization, which compensates for the insufficiency of minerals and may lead to the disappearance of the initial lesion-restitution ad integrum (Vulovic et al., 2002).

In children younger than 18 months, non-invasive treatment of the initial carious lesion is one of the elements of caries risk management (Kobašlija et al., 2012). The question arises when it is best and most effective for the dentist to begin local fluoride treatment.

Considering the fact that the enamel surface of the newly erupted enamel is not yet fully mineralized, and the teeth are most sensitive to cariogenic nicks in the first few months of eruption, local treatment should begin at around two years of age (Rajić and Disan, 1985; Richards, 1999), when most of the child's deciduous teeth are already sprouted.

During the eruption of patients' teeth, there is an accumulation of plaque over a long period of time, as it is impossible to maintain complete oral hygiene in the newborn, and also the surface of the enamel is still porous due to post-traumatic maturation that has just begun. After the teeth are activated, part of the plaque is partially removed from the tooth surface (Carchev, 2006). If oral hygiene is established and the plaque is removed the damaged crystals will be remineralized in the presence of fluorides (Gajic, 1998; Kokoceva-Ivanovska et al., 2017). However, if deposits accumulate over a longer period of time on dental surfaces or in the case when oral hygiene is insufficient or the presence of fluoride is discussable then, the demineralization processes will dominate and predominate, leading to cracking of the surface layer of the enamel and the initial lesion (white spot). This initial lesion first appears at enamel level, and then it can progress in width and depth through the dentinal canals and continuing into depth of dentin, with the possibility of affecting the pulp with complications such as: pulpitis, gangrene, periapical abscesses, etc., has influence on the dental quality.

So the chances of white spot being remineralized, or how long it will remain subclinical before developing into a clinically visible carious lesion, will depend on a number of factors (Vulovic et al., 2002), assumed that caries is a multi-causal disease. How successful remineralization will be depends on the predominant, protective, or/and pathogenic factors (Hicks, 1989; Szoke and Kozma, 1989).

This study aimed to evaluate the effectiveness of topical fluoride as remineralizing agents on the initial carious lesions and superficial carious lesions of circular caries (early childhood caries) in children. Preventive measures without topical fluoride treatment were implemented to one study group. To another study group, we conducted clinical evaluation of the remineralizing effect of three-month and six-month topical application of fluoride preparation in the initial and superficial carious lesions in circular caries (early childhood caries). The comparison of the remineralizing effect between the threemonth and six-month topical fluoride application was also done.

\section{Materials and methods}

\section{Diagnostic of the initial lesion and superficial form of caries}

For realizing the aim of the study, conducted at the Clinic for Pediatric and Preventive Dentistry in Skopje, we included 117 patients aged 1.5 up to 3.5 years, with a fully formed denture, in which with a standard clinical examination, we diagnosed circular caries in the initial stages: initial lesion-white spot (macula alba) and superficial form of circular caries. We made the diagnosis of the initial lesion - macula alba, i.e. the superficial form of caries in the following way professional removal of soft deposits, intensive drying of the vestibular surfaces of the maxillary primary incisions with a booster for 15 seconds

The slight change in the transparency of the enamel in the form of a white spot, without the present cavitation, was used for diagnosis of an initial lesion-white spot lesion (macula alba). 
By examination and probing, we diagnosed the changes in the type of initial cavity in the enamel as a superficial form of caries. We educated mothers with advises for proper maintenance of the patient's hygienicdietary regime, showing how to patient's teeth, and how to guide their patients to a proper and healthy diet (Rummlerand Weiss, 2000). The mothers of the patients who still used the bottle, received instructions for weaning the child from the bottle in the shortest possible time (Moss, 1999).

\section{Clinical follow-up of patients without fluoride treatment}

The patients who were not treated with topical fluoride treatment, were scheduled for regular check-ups once a month, following whether they adhered to our advice. Of these, 31 patients were diagnosed with an initial lesion and 26 ones had a superficial lesion of the maxillary primary incisors. Satisfying the criterion for determining the oral hygiene index, in the control examinations, we determined the OHI index of soft plaques according to the Green-Vermillion method, and then we removed the present soft plaque from the tooth surfaces and gave advice for improving oral hygiene (Hicks et al., 1999; Snjegota and Erdgolija, 2001; Trummler and Weiss, 2000). With such regular checkups, we followed the patients in the following years until the time of the physiological change of the maxillary primary incisions occurred. In addition, we registered which of the initial lesions were biologically repaired, persisted or programmed, and the superficial lesions whether they remained at enamel level or in dentin prograde.

\section{Clinical follow-up of patients treated with topical fluoride treatment}

Remineralizing agents used in this study was commercially available so, for topical fluoride treatment of the patients, we used an amine fluorides solution of 1 $\mathrm{mL}$ of solution containing $10 \mathrm{mg}$ of fluoride (1\%) in the form of olafluor (trade name) $(0.925 \%)$ and dectafluor $(0.075 \%)$, and as auxiliary ingredients are saccharin, aroma 46 and distilled water. The group of 60 patients covered with topical fluoride treatment with this preparation one on week in period of six months, were selected with equal presence at the two initial stages of circular caries, of which 30 patients with initial white spot lesion (macula alba) of circular caries and 30 patients with a superficial form of circular caries. Topical fluoride treatment was performed as follows:

- Professional removal of soft deposits from the tooth surfaces of the maxillary incisions;

- Coating with organic fluoride preparation (amine fluoride), for a period of two minutes, with mandatory use of a dental dryer so that the liquid is not swallowed;

- Excess fluid leakage by the patient (about 30 seconds);

- The patient is advised not to take food or liquid for the next 30 minutes).

\section{Clinical evaluation of the remineralizing effect in initial lesions after the third and six-month of topical fluoride treatment}

For patients with initial lesion, after the third and sixmonth topical fluoride treatment with amine fluoride solution, we conducted a clinical evaluation of the remineralizing effect of organic fluoride salts. During the clinical evaluation, first we dried the vestibular surfaces of the maxillary primary incisors with a powder for 15 seconds, and then with examination and pressure-free probing, we tracked the continuity of the enamel surface and its transparency. After the third month and after the sixth month, of the completion the fluoride treatment, we registered in which of the patients with initial lesion significant or partially positive remineralizing results were achieved, and in which the patients did not achieve results. In this regard, we analyzed in detail the effects of topical fluoride treatment and registered which of the initial lesions were biologically repaired, persisted, or programmed.

With the described regular controls, we followed the treated patients with fluoride treatment in the following years, until the period of physiological change of the teeth, when we again performed clinical evaluation of the effects of the conducted treatment.

In patients with superficial lesions after the third and six-month topical fluoride treatment with amine fluoride solution, we performed clinical evaluation of the remineralizing effect of organic fluoride salts

\section{Statistical method}

Obtained data were statistically processed using the following statistical methods:

- The numerical statistical series were analyzed using the dispersion measures (standard deviation);

- The structure of the attributive statistical series was analyzed using relationships and proportions;

- Correlation between attributive statistical series was performed using Pearson's $\chi 2$ test;

Testing the significance of differences between two arithmetic means and between two proportions in independent samples (between the exanimated groups) was done with the Student's t-test for independent samples.

\section{Results and discussion}

During the clinical examination of our 117 patients aged from 1.5 to 3.5 years $18-42$ months, 61 (52.14\%) were diagnosed with initial lesions (macula alba) on the primary incisors, and $56(47.86 \%)$ patients, with superficial form of circular caries (Tab. 1).

Analysis with the Student t-test of proportion shows 
Table 1. Distribution of the patients at the age from 1.5 to 3.5 years with circular caries of the deciduous teeth according to the initial developmental stages

\begin{tabular}{|c|c|c|c|}
\hline \multicolumn{2}{|c|}{ Total number of patients } & From 18 to 29 & From 30 to 42 \\
\hline & & months & months \\
\hline & & 41 & 76 \\
\hline & & $(35.04 \%)$ & $(64.96 \%)$ \\
\hline \multicolumn{2}{|c|}{ patients with initial lesion } & \multicolumn{2}{|c|}{ patients with superficial lesion } \\
\hline \multicolumn{2}{|c|}{61} & \multicolumn{2}{|c|}{56} \\
\hline \multirow[t]{2}{*}{18 to 29 months } & 30 to 36 & 18 to 29 months & 30 to 42 \\
\hline & months & & months \\
\hline 32 & 29 & 9 & 47 \\
\hline$(52.46 \%)$ & $(47.54 \%)$ & $(16.07 \%)$ & $(83.93 \%)$ \\
\hline
\end{tabular}

that there were statistically significant differences in patients with the superficial lesion, which statistically significantly increased at the age of 30 to 36 months $(\mathrm{p}=$ 0.0001) (Tab.1).

Both forms of circular caries of deciduous teeth in patients aged 1.5 to 3.5 years were more common in female patients, but differences in males were not statistically significant $(\mathrm{p}=0.9136)$. The initial lesion was diagnosed in $27(44.26 \%)$ male and $34(55.74 \%)$ female patients, and $25(44.64 \%)$ male and $31(55.36 \%)$ females had a superficial lesion. Analysis with the Student's proportional t-test showed that there were no statistically significant differences in the occurrence of the initial and superfficial lesion regarding to sex ratio $(p=0.9671)$ (Tab. 2).

The distribution of patients (with initial and superficial lesions) who were treated and not treated with topical fluoride is shown in Table 3. In fact, $49.18 \%$ patients with initial lesions and $53.57 \%$ patients with superficial lesions were treated, respectively. Student's ttest of proportions showed that there were no statistically significant differences between the number of treated or untreated patients with initial and superficial lesions $(\mathrm{p}=$
0.5899). This shows that samples of treated and untreated initial and superficial lesions are taken almost equally, which is one of the conditions for further valid analysis.

For the patients with initial lesion, the clinical evaluation of the remineralizing effect after the treatment with organic fluoride of three months, showed that in 9 (30\%) patient the initial lesions biologically repaired and visually disappeared, while in $21(70 \%)$ it did not occur, until biological repair. Moreover, it was considered that in $19(63.33 \%)$ patients the lesions persisted, and in 2 $(6.67 \%)$ they progressed. The analysis shows that there are statistically significant differences in clinical evaluation before treatment and after topical fluoride treatment for three months old patients $(p=0.0019)$.

The clinical evaluation of the remineralizing effect of organic fluoride salts after six months showed that in $17(56.67 \%)$ patients the initial lesions were biologically repaired, and in $13(43.33 \%)$ biological repair did not occur, i.e. in $11(36.67 \%)$ persisted, and in $2(6.67 \%)$ patients the lesions progressed. The analysis shows that there are statistically significant differences in clinical evaluation before treatment and after topical fluoride treatment for six months $(\mathrm{p}=0.0002)$ (Tab. 4).

Table 2. Distribution of patients with circular caries of deciduous teeth according to the initial developmental stages and gender

\begin{tabular}{cccc}
\hline \hline \multicolumn{2}{c}{ Total number of patients } & male & female \\
$117(100.0 \%)$ & $52(44.44 \%)$ & $65(55.56 \%)$ \\
\hline \multicolumn{2}{c}{ patients with initial lesion } & \multicolumn{2}{c}{ patients with superficial lesion } \\
Male & female & male & female \\
27 & 34 & 25 & 31 \\
$(44.26 \%)$ & $(55.74 \%)$ & $(44.64 \%)$ & $(55.36 \%)$ \\
\hline
\end{tabular}


Table 3. Distribution of patients with circulary caries of deciduous teeth according to the initial developmental stages and topical fluoride treatment

\begin{tabular}{cccc}
\hline \hline \multicolumn{2}{c}{ Patients with initial lesion } & \multicolumn{2}{c}{ Patients with superficial lesion } \\
& $61(100 \%)$ & \multicolumn{2}{c}{$56(100 \%)$} \\
\hline untreated & treated & untreated & treated \\
31 & 30 & 26 & 30 \\
$50.82 \%$ & $49.18 \%$ & $46.43 \%$ & $53.57 \%$ \\
\hline
\end{tabular}

The comparative analysis of the results of the clinical evaluation of the initial lesion in patients aged 1.5 to 3.5 years after three and six months of topical fluoride treatment shows an increase of patients from 9 to 17 with biological reparation, where the differences are statistically significant $(p=0.0392)$.

Analysis with the $\chi 2-$ test shows the correlation between the duration of topical fluoride treatment and the occurrence of biological reparation of the initial lesions in patients aged 1.5 to 3.5 years $(\chi 2=4.34, d f=1, p=$ 0.0371). The clinical evaluation of the initial lesion (macula alba) in a total of 31 same untreated patients at age of six-year-old showed that in $4(12.9 \%)$ patients the lesions biologically repaired and visually disappeared, in $12(38.7 \%)$ persisted, and in 15 ( $48.39 \%)$ progressed. Student's t-test of proportion shows statistically significant differences between untreated and treated patients at the age of six in terms of the clinical evaluation of the initial lesion $(p=0.0352)$. Namely, there was a significantly higher biological repair in treated patients in relation of the untreated.

Analysis with $\chi 2$ test show the correlation between topical fluoride treatment and the occurrence of biological reparation of the initial lesions in six-year-old patients $(\chi 2$ $=4.64, d f=1, p=0.0312)$. However, although remineralization of the initial lesion (white spot) occurs in deeper spots that are no longer white but have a matte or chalky colour, remineralization is not complete because ion transport at depth is limited and the lesion body is never remineralized (Vulovic et al., 2002).

Fluoride converts hydroxyapatite from enamel into fluoropatics that make the tooth more resistant to caries (Mneimne, 2008). It is now widely accepted that fluoride has both systemic and topical modes of action (Richards, 1999). However, today the knowledge about the action of fluoride is based on the fact that its effect is better and greater if it is used locally, i.e. topically. The topical mode of action of fluorides accelerates the remineralization process of the carious lesion, increases the intake of calcium and phosphorus in the crystal lattice, and hydroxyapatite is converted to fluoropatite, which is more resistant to acidic environments (Snjegota and Erdgolija, 2001). The local application of fluoride on hard dental substances in the post-traumatic period, according to most authors dealing with this issue, is the main mechanism of action of fluoride in the prophylaxis of caries in early childhood (Tinanoff et al., 1999; Trummler and Weiss, 2000). There are various fluoride agents available in various forms: toothpastes, rinses, solutions, gels, jellies, varnishes, etc. (Vutov, 1984). However, it is necessary to emphasize that the frequency of fluoride preparation should be directly related to the patient's risk of caries, and the choice of preparation should be the choice of the dentist. What and how much fluoride is used will depend on which group the patient belongs to in relation to caries risk, but also what is the systemic exposure to fluoride intake by water. Topical application of concentrated fluoride preparations (solutions, varnishes, jellies) with a concentration of 10,000-23,000 ppm F, confirmed that caries reduction of $33-40 \%$ is achieved. Their application should be performed exclusively professionally in an outpatient setting, due to the possibility of aspiration of excess highly concentrated fluoride. In children, topical application can be performed with concentrated fluoride agents normally between 5 and 6 years of age. However, in the case of children with very high risk of caries, such as early childhood caries (Snjegota and Erdgolija, 2001), exceptions are made and the time when topical application should be started is modified. So, it is required to start with treatment much earlier, immediately after the eruption of all deciduous teeth in the oral cavity, and in exceptional cases earlier. However, it has to be noted that in this case, pediatric dentist must be extremely careful and professional, because these young patients still do not know how to spit. Therefore, the application must be performed strictly in an outpatient setting in the presence of the parent, with the greatest precautions, use of a dental dryer and preferably waterproof, so as not to be swallowed by excess preparation (Atanasov and Markova, 2001).

Maatouk et al. (2000), Muller (1996) and Schmid et al. (1964), introduced amine fluorides into the dental profession, giving preference to organic fluorides over inorganic ones as agents with a more pronounced karyostatic and plaque reduction effect. This was first supported in vitro, and then with data from animal experiments Furthermore, several clinical longitudinal studies have been performed with amine fluoridecontaining gels. Tinanoff, et al. (1970) by brushing their 
Table 4. Clinical evaluation of the initial lesion in patients aged 1.5 to 3.5 years after three and six months of topical fluoride treatment

\begin{tabular}{ccccc}
\hline $\begin{array}{c}\text { Lasting period of topical fluoride } \\
\text { treatment }\end{array}$ & $\begin{array}{c}\text { Patient with biological } \\
\text { reparation of teeth }\end{array}$ & $\begin{array}{c}\text { Patient with } \\
\text { persisted } \\
\text { teeth } \\
\text { condition }\end{array}$ & $\begin{array}{c}\text { Patients with } \\
\text { clinical } \\
\text { progression }\end{array}$ & $\begin{array}{c}\text { Total number } \\
\text { of patients }\end{array}$ \\
\hline 3 months & 9 & 19 & 2 & 30 \\
6 months & $(30.00 \%)$ & $(63.33 \%)$ & $(6.67 \%)$ & $(100 \%)$ \\
& 17 & 11 & 2 & 30 \\
$(56.67 \%)$ & $(36.67 \%)$ & $(6.67 \%)$ & $(100 \%)$ \\
\hline
\end{tabular}

teeth with an amine fluoride gel, in a three-year longitudinal study for patients of 3 years' age, have achieved a reduction in circular caries by up to $45 \%$ (almost half, which is considered a great success). One of the means of concentrated fluoride solutions, from the group of organic fluorides, used for topical application in children with very high caries risk at the earliest age in circular caries, in addition to amine fluoride gel was the amine fluoride solution with topical application of an amine fluoride gel strictly in an outpatient setting and cautiously, by coating once a week in 250 children aged 3 to 4 years, at very high risk of caries, reduced circular caries and up to 53\% (Snjegota and Erdgolija, 2001). Over time, in the pediatric dental profession, modern companies produce more modern and newer fluoride preparations.

\section{Conclusion}

According the results of the our study it can be summarised that in the patients with both macular degeneration: initial lesion (macula alba) and superficial form, topical fluoride treatment greatly affected the repair and reversal of the initial lesion and the chronicity of the superficial caries. It was revealed that the remineralization effect of the topical fluoride treatment shows the significant difference in the longer (six-month) period of application compared to the three-month period. This finding led to the conclusion that a longer period of continuous topical fluoride treatment gives better results. Our study have again proven the positive effects of fluorides in preventing caries and it can be suggested among the best preventive strategy in childhood at an early age.

\section{References}

Amaechi, B.T., Van Loveren, C., 2013. Fluorides and nonfluoride remineralization systems, in: van Loveren, C. (ed.) Toothpastes. Monogr oral Sci. Basel, Karger, pp. 1526.

Atanasov, N., Markova, N., 2001. Early Childhood Caries (ECC) - Our point of view. Balk. J. Stom 5(2), 83-87.

Biesbrock, A.R., Faller, R.V., Bartizek, R.D., Court, L.K., McClanahan, S.F., 1998. Reversal of incipient and radiographic caries through the use of sodium and stannous fluoride dentifrices in a clinical trial. J. Clin. Dent. 9(1), 5-10.

Cate, J.M., Arends, J., 1980. Remineralization of artificial enamel lesions in vitro: III. A study of the depositionmechanism. Caries Res. 14(6), 351-358. Available at: https://doi.org/10.1159/000260477.

Carević, M., Vulović, M., Šindolić,M., 2009. An integrated approach in combating early childhood caries. Balk. J. Stom. 13, 15-20.

Carčev, M., 2006. Preventive Dentistry. Faculty of Dentistry, Ss Cyril \& Methodius University, Skopje.

Cochrane, N.J., Saranathan, S., Cai, F., Cross, K.J., Reynolds, E.C., 2008. Enamel subsurface lesion remineralization with casein phosphopeptide stabilised solutions of calcium, phosphate and fluoride. Caries Res. 42(2), 88-97. Available at: https://doi.org/10.1159/000113161.

Gajic, M., 1998. Fluoridi u preventivnojstomatologiji. ICN Jugoslavia, Beograd.

Hicks, J., Wild, T., Flaitz, C.M., Seybold, S., 2004. Fluoride varnishes and caries development in primary tooth enamel: an in vitro study. J. Dent. Child. 68(5-6), 304310.

Hoyer, I., Gaengler, P., Bimberg, R., 1984. In vivo remineralization of human enamel and dental calculus formation. J. Dent. Res. 63(9), 1136-1139. Available at: https://doi.org/10.1177/00220345840630090801.

International Caries Classification and Management System (ICCMS ${ }^{\mathrm{TM}}$ ), 2014. Guide for Practitioners and Educators. Available at: https://www.iccmsweb.com/uploads/asset/59284654c0a6f822230100.pdf

Kobašlija, S., Vulićević, Z., Jurić, Hisar, 2012. Minimalna invazivna terapija. Sarajevo: Dobra knjiga, Sarajevo.

Kokoceva-Ivanovska, O., 2011. Early childhood caries: Following the early developing stages and possibilities for its prevention. Ph.D. Thesis, 137-159. Faculty of Dental Medicine, Ss Cyril \& Methodius University, Skopje. 
Kokoceva-Ivanovska, O., Jankulovska, M., Mijoska, A., Zabokova-Bilbilova, E., Pavlevska, M., Todorovska, G., 2017. Ultrastructural changes of the initial lesion at early childhood caries. Journal of International Dental and Medical Research 10(1), 36-41.

Louloudiadis, K., 2001. Prevention of early childhood caries. Balk. J. Stom. 5(2), 77-82. Available at: https://www.ebass.org/journal/2014v18/BJDM-18-1.pdf

Lynch, R.J., Smith, S.R., 2012. Remineralization agents - new and effective or just marketing hype? Adv. Dent. Res. 24(2), 63-67. Available at: https://doi.org/10.1177/0022034512454295.

Maatouk, P., Ghedira, H., Imour, B., Iaapoura, M., 2000. Preschool children oral preventive programs in 2000: better late than never. Int. Dent. J. 50(6), 338-340.

Mneimne, M., Hill, R.G., Bushby, A.J., Brauer, D.S., 2008. High phosphate content significantly increases apatite formation of fluoride-containing bioactive glasses. Acta Biomater. 7(4), 1827-1834. Available at: https://doi.org/10.1016/j.actbio.2010.11.037

Moss, S., 1999. The oral dynamics of caries prevention: changings concepts. $1 \mathrm{~V}$ Congress of the Balkan Stomatological Society (Abstracts) Istanbul 25.

Nursing- bottle syndrome: Risk factors. J. Dent. Child. 63(1), 42-50.

Rajić, J., Disan, Z., 1985. Decja i preventivna stomatologija. Zagreb: Jumena, Zagreb.

Richards, A., 1999. Fluoride. IV Congress of the Balkan Stomatological Society (Abstracts) Istanbul: Balkan Stomatological Society 27(3).
Roopa, K.B., Pathak, S., Poornima, P., Neena, I.E., 2015. White spot lesions: A literature review. J. Pediatr. Dent. 3(1), 1-7. Available at: https://doi.org/10.4103/2321-6646.151839.

Snjegota, S., Erdgolija, Lj., 2001. Fluor prophylaxis and caries characteristics in the children aged 3 to 4 , VI Congress of the Balkan Stomatological Society (Abstracts) Bucharest: Balkan Stomatological Society 184(9).

Szoke, J., Kozma, M., 1989. Results of three-year study brushing teeth with amine fluoride gel. Oral Prof. 11, 137143.

Tinanoff, N., Daley, N.O., Sulliva, D., Douglass, J., 1999. Failure of intense preventive efforts to arrest early childhood and rampant caries: three cases. Pediatric dentistry 21(3), 160-163.

Trummler, A., Weiss, 2000. Results of caries prevention programme in patients after 33 years. Int. Dent. J. 50(6), 340-341.

Vashisht, R., Indira, R., Ramachandran, S., Kumar, A., Srinivasan, M.R., 2013. Role of casein phosphor peptide amorphous calcium phosphate in remineralization of white spot lesions and inhibition of Streptococcus mutants? J. Conserv. Dent. 16(4), 342-346. Available at: https://doi.org/10.4103/0972-0707.114370.

Vulovic, M., Beloica, D., Gajic, M., Stefanovic, R., 2002. Preventivna stomatologija. Elit Medica, Beograd.

Vutov, M., 1984. Lechenie na stomatologichni zaboliavaniia $\mathrm{v}$ detskata vŭzrast: Meditsina i fizkultura, Sofiia.

Weinstein, P., Domato, P., Koday, M., Leroux, B., 1994. Results of a promising open trial to prevent baby bottle tooth decay: A fluoride varnish study. J. Dent. Child. 61(5-6), 338-341.

\title{
Почетните фази на кариесот на раното детство (циркуларен кариес) - клиничка евалуација на реминерализација
}

\section{Олга Кокочева-Ивановска}

\author{
Клиника за детска и превентивна стоматологија, Стоматолошки факултет, \\ Универзитет „Св. Кирил и Методиј“, Мајка Тереза 17,1000 Скопје, \\ Република Северна Македонија
}

Клучни зборови: циркуларен кариес, кариес на рано детство, реминерализација, иницијална лезија, бело петно

Кариесот на раното детство може да се јави уште во најраната возраст, со ерупцијата на млечните заби на возраст од 1-1,5 години. Ова е мулти факторијално дентално заболување кое претставува проблем од светски размери, со многу висока преваленција во последните декади. Цел на испитувањето беше да се направи клиничка евалуација на ефектот на реминерализацијата од топикалниот флуориден третман кај пациенти во почетни стадиуми на циркуларен кариес. 
Ова студија беше спроведена на Клиниката за детска и превентивна стоматологија во Скопје, и беа вклучени 117 пациенти од двата пола, со почетни развојни фази на циркуларен кариес, на возраст (1,5-3,5 години) со комплетно формирано млечно забало. Од нив беа селектирани 61 пациент со иницијална лезија - бела дамка и 56 пациенти со суперфицијална форма. Од двете групи, по 30 пациенти беа третирани со топикален флуориден препарат, во период од шест месеци, аплициран еднаш неделно. Преостанатите пациенти имаа редовни контроли и инструкции, но не беа подложени на флуориден третман.

После завршувањето на флуоридниот третман го следевме реминерализирачкиот ефект односно кои иницијални лезии се ревертираа или кај кои дојде до пополнување на интракристалните простори и репарирање на кристалите после шестмесечната топикална апликација. Кај некои пациенти кај кои успеавме да ги задоволиме и другите превентивни фактори, успеавме да добиеме клиничка слика на комплетна реминерализација на иницијалната лезија in vivo (restitution ad integrum), приближно слично како кај здрав заб. Колку ке биде успешна реминерализацијата зависи од тоа кои фактори ќе преовладуваат, протективните или патогените. 